\title{
Thematic Opinion \\ Waste management scheme and way forward for during and post COVID-19
}

\author{
Rabindra Prasad Dhakal ${ }^{1 *}$ \\ ${ }^{1}$ Faculty of Technology, Nepal Academy of Science and technology, Khumaltar, Lalitpur, Nepal \\ ORCID: 0000-0002-7091-7821
}

Received: May 24, 2020; Accepted: June 22, 2020; Published: June 23, 2020

\begin{abstract}
The SARS-CoV-2 or/andCOVID-19 may have contaminated the wastes, which need especial precaution as suggested by WHO guidelines. WHO also suggested that no cases have been reported of infection from the waste workers working on infected wastes so far. However, in case of Nepal, 50\% wastes used to be collected at the time 2011, which seems significantly improving as high as $81 \%$ in sampled areas. In COVID period, the concern was raised on safety issues of waste workers as suggested by RDT positive, hence, the public perception of waste management, the scope of recycling of wastes and up streaming of waste materials as economical commodities with proper intervention of technologies, awareness and behavior is incorporated in this study. It is estimated that the total Plastic wastes of major city centers could be significantly turned into useful products including fuel. For example, Kathmandu Valley can extract 24,298 KL oil from wastes plastics, which is based on calculation of waste per capita, waste composition and conversion ratio. Hence, the COVID-19 pandemic could be turn into opportunities in the sector of waste management provided we act wisely.
\end{abstract}

Keywords: contagious waste management; post-COVID-19 waste management approach; SARS-CoV-2; waste plastics management

सारांश: SARS-CoV-2 अथवा COVID-19 ले कुनै पनि फोहोरलाई संक्रमित गरेको हुन सक्छ भन्ने आधारमा विश्व स्वास्थ्य संगठनले भने बमोजिम बिशेष साबधानी अपनाउनु जरुरी छ तर बिश्व स्वास्थ्य संगठनले संक्रमित फोहोर संकलन गरेकै कारण हालसम्म त्यस्ता संक्रमण फैलिएको कुनै आधार भेटिएको छैन पनि भनेको छ। नेपालको हकमा २०११मा करिब पू०ू फोहोर संकलन गरिने गरेकोमा हाल आएर यस अध्ययनमा गरिएको सर्बेक्षणको आधारमा ५१५ जति संकलन भै रहेको देखिन्छा कोभिड महामारीको बेलामा फोहोर संकलनमा संलग्न हुनेहरुमा RDT पोजिटिभ देखिएको हुँदा उनीहरुको सुरक्षाको लागि सर्बसाधारणको फोहोर ब्यबस्थापनमा सहभागिता, रुची र धारणा लगायत फोहोरको पुनर्प्रयोग र पुनर्चक्रिय सम्भाबनाका साथै तिनीहरुलाई प्रबिधि र जनचेतनाको माध्यमबाट आर्थिक हिस्सामा सहभागी हुन सक्ने बस्तुको रुपमा रुपान्तरणको सम्भाबनाको बारेमा अध्ययन गरिएको छ । शहरका फोहोर प्लास्टिकलाई इन्धनमा परिणत गर्दा शहरमा कति इन्धन निस्कन्छ भन्ने अनुमान गरिएको छ। उदाहरणको लागि काठमाडौं उपत्यकाबाट बार्षिक २४,२९६ किलोलिटर निस्कन्छ। त्यसैले यदि हामीले बुद्धिमता ढंगले काम गयौं भने यो कोभिड महामारीले फोहोरमैला ब्यबस्थापनको क्षेत्रमा मौकाको रुपमा परिणत पनि हुन सक्नेछ।

\footnotetext{
* Corresponding author, E-mail: dhakalrabindra3@gmail.com; Tel.: +977-1-5550813

(c) RECAST/TU
} 


\section{Introduction}

The Novel Corona Virus-2019(n-cov-19), also called SARS-CoV-2, was first identified in Wuhan, China in December, 2019. (Centers for Disease Control and Prevention, 2020; European Centers for Disease Control, 2020). With the exception of asymptomatic cases, the proportion of which remains yet to be confirmed further, infection with the virus is associated with an illness known as 'COVID-19' is characterized most frequently by respiratory infection, which can progress to pneumonia, severe lung damage and death(CDC, US, May 2020; ECDC May, 2020; ECDC Diseases, May 2020).A pivotal point is that no respiratory virus, including SARS-CoV, MERS$\mathrm{CoV}$, and influenza viruses have ever been confirmed as transfusion-transmissible by any blood product (APBN White Paper 2019, Transfusion news, 2020).

It is worth noting that, according to the Centers for Disease Control and Prevention (CDC), touching a surface or object contaminated with the virus and then touching one's own face is not the main way the virus spread In May, the CDC updated its guidance to say that COVID-19 spreads "very easily" from person to person through contaminated droplets produced by others as they talk, cough, sneeze and breath, especially in enclosed spaces. One aspect that has been unclear is exactly how long SARS-CoV-2, can survive outside the human body. Some studies on other corona viruses, including SARS and MERS, found they can survive on metal, glass and plastic for as long as nine days, unless they are properly disinfected. The virus can travel through the air in respiratory droplets produced when a sick person breathes, talks, coughs or sneezes. Referring to WHO, the Ministry of Health, Government of Nepal, also said that the virus can survive for up to 72 hours on plastic and steel surfaces, and 24 hours on cardboard, Some can even hang around for up to 28 days in low temperatures.

Hence, most important issue is, containment of virus if any in the trash that has to be tightly packed. It is also know that the plastic bags are the best materials to pack the trash tightly inside so that dissemination could be avoided. However, using plastic bags are not considered as friendly in the general perception of the wider societies in Nepal. Not only that the government decision was published in the official gazette on April 1, 2015 stated that the import, storage, sale and use of plastic bags that are smaller than 20 inches in width and 35 inches in length and thinner than 40 micron cannot be used in the three districts of Kathmandu Valley. Unfortunately, 12 days later of the decree made by the GoN, there was mega-earthquake that creates havocs among the general public and the situation became more plastics demanding as packed food and relief packages focusing on their convenience. Similarly, the another calamities now came to us, the SARS- CoV-2 pandemic, which demand more plastics use in the form of PPE including Face shield and mask, gloves, boots and others. (WHO-WASH, 2020)

WHO has indicated that there is no evidence of dissemination of COVID-19 by direct contamination to the unprotected waste workers, which in fact should be collected safely and cautiously if it is infected as suggested by the WHO guidelines. The waste should be treated, preferably on-site, and then could be safely disposed. If transportations needed, it is critical to understand where and how it will be treated and disposed. Contaminated waste should be disinfected first, or autoclaved. WHO Guidelines suggested that all wastes from the infected people should be tightly packed and handed over to the waste workers. Waste generated at home during quarantine, while caring for a sick family member or during the recovery period should be packed in strong black bags and closed completely before the disposal and eventual collection by municipal waste services. Tissues or other materials used when sneezing or coughing should immediately be thrown in a waste bin. After such disposal, correct hand hygiene should be performed (US, FDA Blood Transfusion, 2020; WHO Hygiene and Sanitation Guidelines, 2020).

It is known fact that urbanization is ever expanding, where consumerism culture could be prevail in coming days that makes more wastes to be generated, organic wastes would be shrunk and inorganic wastes could be expanded. Nepal, which is ever focusing on solid waste transfer rather than management, has continuously not only deteriorating the environment and public health but also looses the useful and functional resources. The review and some recent study have clearly indicated that there is some transitional scope of waste management after COVID-19 Pandemic (Dhakal, 2019).

\section{State of the art review, challenges, and opportunities}

The waste management issues always remain in darker side of the society, which is fully ignored by the whole mechanism that makes wastes neither properly handled, nor managed, nor adequately recycled yet. There is a substantial change in the volume of waste collection if we compare for last 20 years, which had nearly $50 \%$ of collection rate. But the matter of fact is mere collection doesn't suffice the demand of integrated approach of waste 
management and its scope. The urbanization in Nepal is rapidly increasing, where waste generation is ever expanding and moving out of the capital city.

As we know that as of 2011 (ADB Report, 2013) per capita waste generation is $317 \mathrm{~g} /$ day and it also suggested that half of it get collected. It could be presumed that the percent is bit improving these days as local government is formed and get autonomy to manage under its jurisdiction. More importantly recently declared metropolitan city or adjoining municipalities has also shown some remarkable trends of waste collection and transfer, but not management scheme started as of the study period. One of our studies in Biratnagar Metropolitan City and 3 other municipalities in Jhapa District of province No.1 suggested that $81 \%$ of wastes get collected and transferred to assigned site of local Municipalities that is landfill site of corresponding local government (Survey Report, 2018). The data also shows that some bad practices of waste collection and disposal scheme have been surfaced as depicted in Fig. 1.

\section{Waste disposal scheme}

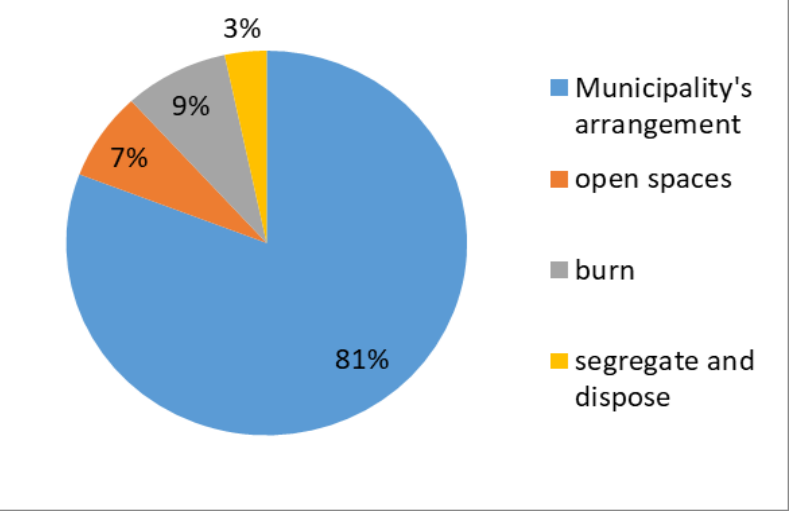

Figure 1. Graphical representation of waste collection/disposal Scheme in Province 1 in its representative cities.

No matter when and where the wastes are generated, they need to be segregated, transported and processed as much as possible and dumped. But in the context of COVID-19, the collection should be more cautious. As suggested by WHO, they need to be sterilized at the site and collectors should be equipped with personal protective equipment. RDT positive cases and PCR negative is indicative of infection at any prior time of the PCR testing, which may not be proved how it was originated but indicated that there could be out break at any time in future during waste handling(The Himalayan Times, May 15). There was also a story from Province No.
5 that the deceased body didn't get permission from local community people and family were even barred to performed their last rites as security forces buried without presence of bereaved family (The Rising Nepal ,). The dead body is also now covered by the plastic to avoid dispersions of the viruses. This is not story all about, it is the indicative scene how society may react to the corona infection crisis and handle it in case of wide spread of epidemics in the country.

Hence, the major challenges of waste management are as follows:

1. The wastes are not generally air tight packed while disposing, and even using plastics is not enough to contain the spread.

2. Low number of tracking, tracing and testing indicated that any households could be infectious or say contagious

3. Any waste stuff could be infectious in the sack of wastes, which is generally handled by the waste workers, as most of them are working all the way without having any protective equipment.

4. There are low level of chemicals, infrastructure and other resources available to sterilize, or disinfect them

5. The public denial is about to sprout to dump the wastes in their territory in the light of suspecting SARS-COV-2 existence in the wastes.

\subsection{Opportunities}

1.Behavior changes: With fear of contamination, $50 \%$ of waste collection pattern in 2011, which have seen $81 \%$ in some urban areas of our studies could turn into $100 \%$ as of now as no one wants to posses the suspicious wastes in their yard.

2.Technology Use: there is almost no waste processing facilities in the country, the emerging concept could create positive stimulants to have some incinerators, disinfectants tunnels and spray, and waste packaging machineries may come to roll out in future.

3.Sanitation issues: Misconception about preferences of virus in wastes may inspire waste workers use PPE and sanitize them in regular basis even for future. Is more likely that WASH sector will get proper attention even in future with insignificant social campaigns.

4.Management: Local government may think processing facilities could be destiny for any kind of wastes and is the only solution to contain the microorganism spread.

Hence, according to the integrative approach of waste management, the pyramid we have used so far, which is still different than other countries, could turn upside down where we could more focus on energy and materials recovery and safely 


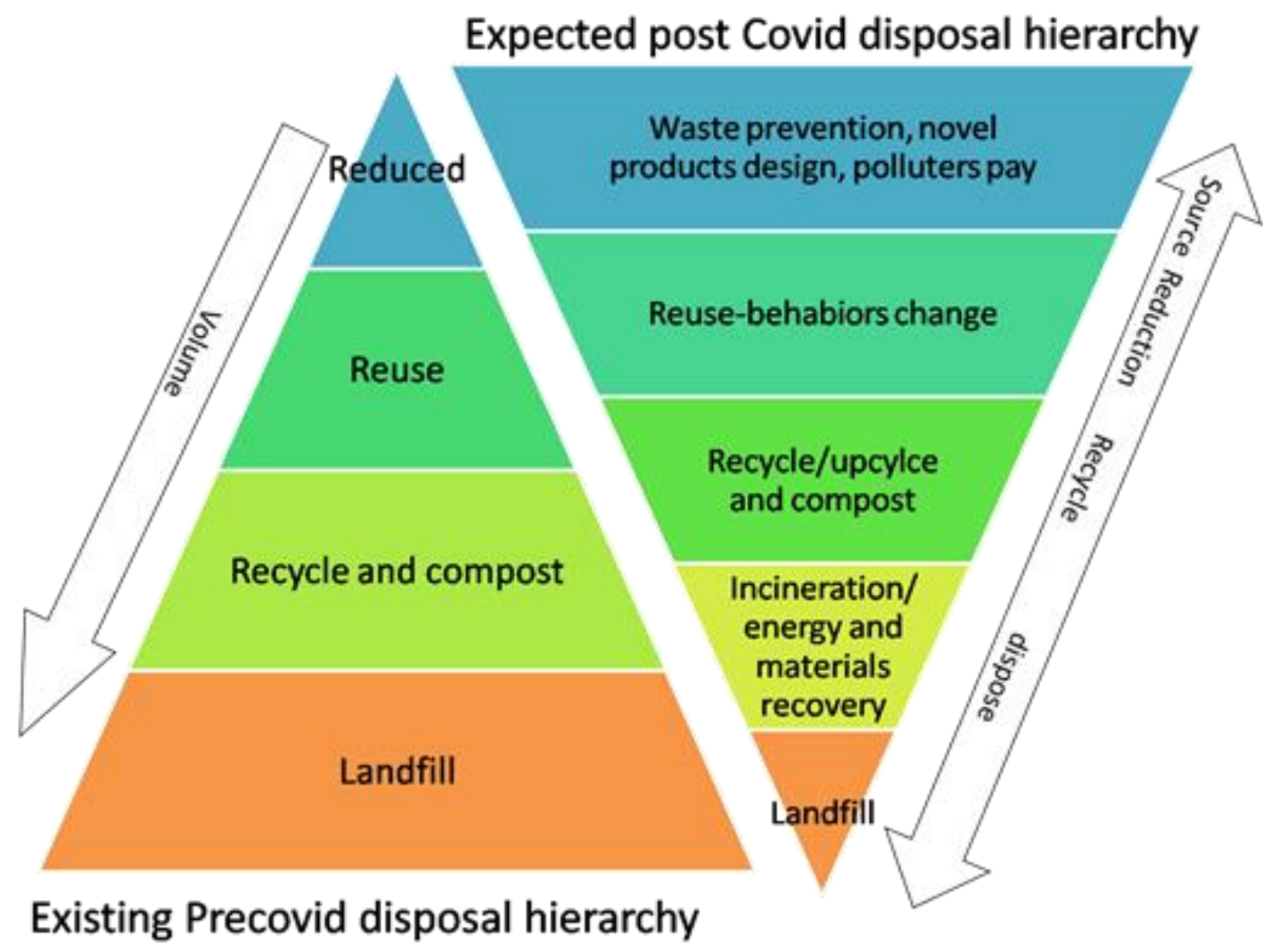

Figure 2. Schematic representation of Pre and post COVID scenario of waste management hierarchy.

manage the remaining wastes as per public concern. to evaluate their choices. The study found that only Currently, the people are seeing all wastes coming $11 \%$ of total population surveyed still preferred out of home is equivalent to medical wastes as every current practices of land filling, where as $27 \%$ prefer pouch could be considered as full of biohazard, recycling while majority of the respondents $(61 \%)$ which may reduce the tendency of manual recycling prefer fuel extraction from waste plastics. This and reuse policy and trend but assuming that COVID response was also prior to COVID-19, hence, it could scenario doesn't exist for long. In any case, be assumed that this response could be slightly technological intervention may come to the fore front differed as of now having COVID epidemic in mind. in near future so that energy harnessing and materials recovery approach could be prevail so that post COVID-19 scenario would be blessing to waste management sector. It is presumed that existing practice of low level of waste reduction and reuse tendency is slowly moving towards some recycling and composting trends but majority of the wastes is still going to landfill sites. However, we could assume that the post COVID Scenario may transpire the general public and administrator for behavior change and moved towards waste prevention, Technology acquisition, reuse the waste materials as much as possible, recycle or upcycle as when the technology available and if not possible may tend to harness the energy by any means and finally very few wastes may go to the landfill sites as depicted in Fig.2.

\section{Role of the Field in Nation's Economy}

As the country prospering, the waste generation per capita of 317g/day as of 2011( ADB Report, 2013) could have substantially changed as of now with decreasing percentage of biodegradable wastes against the other materials, that also inferred that recycling economy could be bigger, less cost intensive and benign for the environment. Increased use of plastic wastes, which is again best use in any calamities as we have recently seen its importance, could served increased volume of waste plastics against any other materials in short future, but, it may provoke the general public to use such kind of stuffs in long run, that may put extra weight on plastic proportions against the other waste materials in future. Having said that plastic recovery could be

To validate this perspective, we have also prime concern in future where as manufacturing of conducted the social survey in 250 households, 115 PPE and its recycling with disinfecting them could institutions including shops, malls, factories and be another venture for novel entrepreneurs that may school as sample in the study area at province No.1 
eventually put extra volume of waste plastics could come to such recycling businesses.

So processing, recycling/upcycling or energy harnessing of 3.3Million ton of wastes, in which 12$18 \%$ of waste proportion could be plastics, that come to economical basket for further use. Based on the secondary data, it is estimated that huge amount $(237,000 \mathrm{KL})$ fuel could be obtained and other clusters of the cities could extract oil as mentioned in Fig. 4 based on population of concerned area and
ADB Report, 2013. As the wastes are in conveyer, the street could be clean and people are in healthy mood and so it could invite many visitors to observe another Visit Nepal20XX. So, energy recovery, employment generation, environmental protection and supporting cyclic economy could be achieved as outcome of COVID-19 crisis.

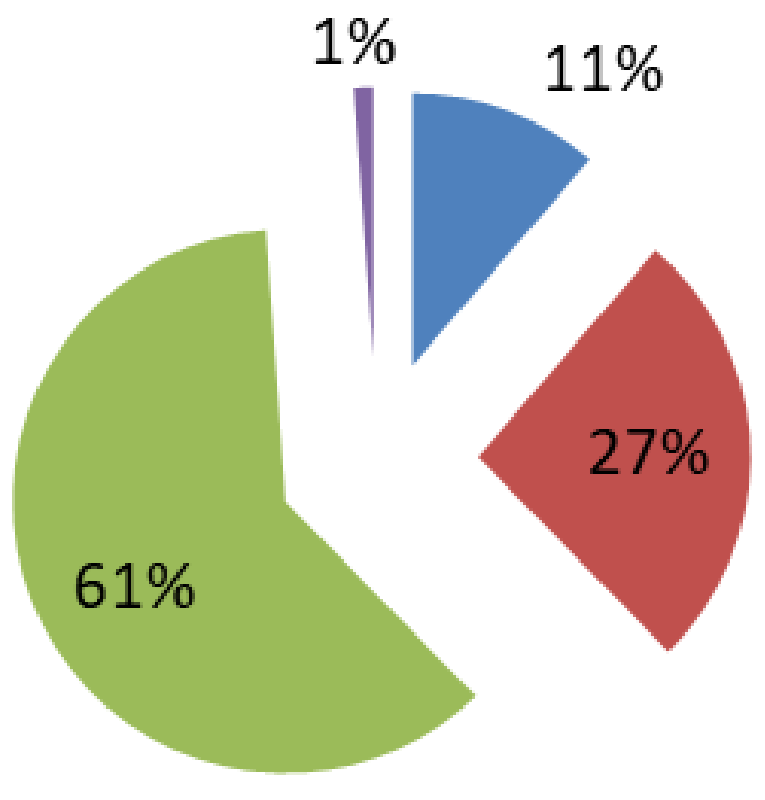

- landfilling

recycling

fuel

conversion

any but

other option

Figure 3. Percentage distribution of public choice of waste plastic management.

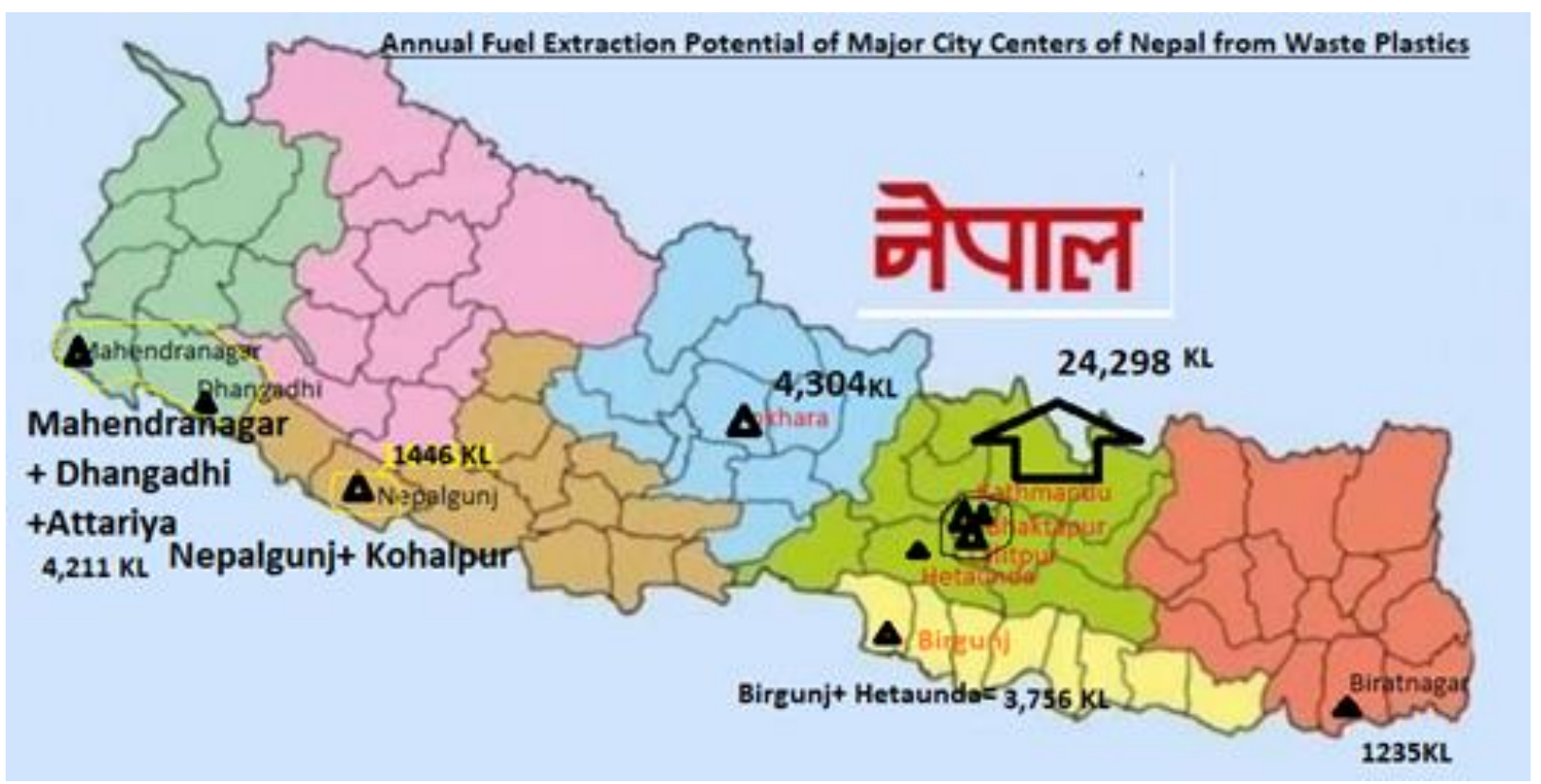

Figure 4. Estimation of annual production scope of fuel from waste plastics in different Cities Center of Nepal. 


\section{Ways Forwards}

As COVID-19 surges up, the infected wastes also could be expanded and goes beyond to the limit to handle effectively, if it is contagious and spread to nationwide. But mechanization of the collection, disinfecting from the distance and automation of the processing could be the best solution to which local government should consult with concern experts for the purpose. It is not as easy as assumed that every waste cautiously handled, segregated, collected, processed and finally disposed as less as possible after harnessing useful materials and energy out of it. On these bases, it could be suggested that the following activities could be taken into account:

1. Contagious or suspected contagious waste materials collected from the hospitals, quarantines, isolated homes should be differently processed segregating from non-infected households wastes during the COVID-19 period.

2. The waste management scheme should come to new height of mechanization and automation of the process that should include recycling, energy and materials recovery.

3. Increased volume of waste plastics in the form of PPE and also packaging of food and waste materials has to be converted into more useful products as it is the most universal recyclable materials.

4. The novel waste management mechanism has to be formulated in the country considering the societal consciousness level and regulating the waste disposal process focusing on international norms and practices.

\section{Conclusions and Recommendations}

The infected wastes from hospitals, quarantine centers, isolated homes and other possible areas could be cautiously collected and handled so that SARS-CoV-2 couldn't be spread out of waste collection stations. The normal households' wastes could also be collected with high alertness and safety during COVID-19 period. After COVID-19 arena, such alertness is not necessary all the times but of course energy recovery and materials recycling and upcyling should be opted as projected in the integrated hierarchical approaches depicted in Fig.2.

\section{Acknowledgments}

Some part of this work is derived from "Survey Report on current status of Plastic wastes and its scope for management in Province No.1" as author has designed the survey and submitted the report to the Ministry of Social Development, Province No. 1.
The Physical survey was conducted by Ms. Swechchaa Raut, Ms. Anandita Dhakal, Ms. Binita Rimal, Ms. Ayushma Singh and Ms. Sushma Karki in cooperation of Municipalities there in. The author would like to acknowledge them all.

Conflict of interests: Nothing to declare

Ethical approval: Not applicable.

Funding: Nepal Academy of Science and Technology, Government of Nepal \& Government of Bagmati Province.

\section{References}

ADB. Solid Waste Management in Nepal Current Status and Policy Recommendations, Asian Development Bank (ADB), (2013)

APBN Rapid Brief White Paper 2019 Novel Corona virus (SARS-CoV-2); Expected challenges and risks to blood safety, Prepared at $17^{\text {th }}$ February 2020.

CDC. Corona Virus Disease 2019 (COVID-19) Situation summary updated March 26, 2020) [Accessed April 01, 2020

Devkota DC, Watanabe K, Dangol V. Need for Alternative Approaches in Solid Waste Management - Case Study Kathmandu Valley. 30 ${ }^{\text {th }}$ WEC International Conference: A People Centered Approaches to Water and Environmental Sanitation, Vientiane, Lao PDR. 2004.

Dhakal RP. Sustainable Management of Plastic Wastes of Urban Nepal by a Novel Technology: Scope, Economy and Environmental Impact(Book Chapter), 310-327, Technological Innovation and management for Sustainable Development, NAM S\&T Center, Allied Publishers Pvt. Ltd., 2019, ISBN 978-93-997-90-5

ECDC. European center for Disease Control Disease background of COVID-19 (updated March 31, 2020) [Accessed April 01, 2020)

https://risingnepaldaily.com/featured/na-disposes-dead-bodyof-covid-19-infected-person-in-jungle,22 May, 2020.

https://thehimalayantimes.com/kathmandu/31-waste-mgmtemployees-of-kathmandu-metropolis-test-positive-on-rdt/

Survey Report on current status of Plastic wastes and its scope for management in Province No.1, The Ministry of Social Development, Province No.1. 2018.

Transfusion news: https://transfusionnews.com/2020/03/04/risk-oftransfusion-transmission-of-sars-cov-2-is-onlytheoretical/ (March 04, 2020) [Accessed April 01, 2020]

U.S. FDA. Updated Information for Blood Establishments Regarding the Novel Corona virus Outbreak March 11, 2020) [Accessed April 01, 2020]

WHO-WASH. Water, sanitation, hygiene, and waste management for the COVID-19 virus Interim guidance, 23 April 2020, WHO/2019-nCoV/IPC_WASH/2020.3 